\title{
Measuring the Unemployment Risk in Northern Greece from the LFS Micro-Data during the Period 1994-2006
}

\author{
STAVROS RODOKANAKIS \\ Department of Social and Policy Sciences, University of Bath \\ VASILEIOS A. VLACHOS \\ Department of European and International Studies, \\ University of Macedonia
}

\begin{abstract}
This paper investigates unemployment risk and job prospects of individuals in the three Northern Greek regions (Central Macedonia, Western Macedonia, and Eastern Macedonia and Thrace), during the implementation of the second (1994-99) and the third (2000-06) Community Support Frameworks. More specifically, the research focuses on the social and demographic characteristics that increase the chances of individuals in finding a job, and explores the impact of gender, age, marital status, residence location, level of education, immigrant status, registered in the Manpower Employment Organization (OAED) and participation in training courses. Furthermore, there is an investigation whether University graduates face greater difficulties in finding a job than non-University graduates, as a series of studies or aggregate statistics for Greece conclude. Sampling is based on individual anonymized records (micro-data) of the Labour Force Survey for both employed and unemployed at Nomenclature of Territorial Units for Statistics-2 level. The findings of the logit model are mixed for all the variables used, apart from those of registered in OAED for which the results have no differences among regions and years.
\end{abstract}

Keywords: Cross-sectional models; Labour economics policies; Human capital; Skills; Unemployment models; Regional, urban and rural analyses.

JEL Classifications: C21, J08, J24, J64, O18

\section{Introduction}

The aim of this paper is to study the impact that various social and demographic characteristics had on the labour market in the three Northern Greek regions: Central Macedonia, Western Macedonia, and Eastern Macedonia and Thrace, during the

(C) 2012 Stavros Rodokanakis Vasileios A. Vlachos. Licensed under the Creative Commons Attribution - Noncommercial 3.0 Licence (http://creativecommons.org/licenses/by-nc/3.0/. Available at http://rofea.org. 
implementation of the Community Support Framework - CSF-2 (1994-99) and the CSF3(2000-06).

The total population of the above three regions constitute about $25 \%$ of Greece's total, namely one out of four Greeks live in Northern Greece, whereas the second major urban centre in the country, Thessaloniki, is situated in Central Macedonia.

The main questions to be answered are, first, what are the social and demographic characteristics that increase the chances of someone in the examined population finding a job, second, whether University graduates, in contrast to most of the rest of the EU member states, face greater difficulties in finding a job than the non-University graduates, as a series of studies (see Meghir et al., 1989; OECD, 1990; Iliades, 1995; IN.E./GSEE-ADEDY, 1999; Katsikas, 2005) or aggregate statistics (Labour Force Survey; Eurostat: Education and Employment Prospects, 1995) for Greece conclude, and third, how does the participation in training courses affect the chances of getting an employment?

We test the human capital theory, which underpins many of the important developments in modern economics and provides one of the main explanations for wage and salary differentials by age and occupation, and the uneven incidence of unemployment by skill (education and training). We examine whether the more educated and the more trained a person is, the higher the probability of him finding a job. We cannot examine the impact of training on earnings, because this kind of information does not exist in the questionnaire of the Greek Labour Force Survey (LFS).

Previous labour market studies for Greece were based on qualitative research and LFS aggregated data. Our analysis of investigating the unemployment risk in the Greek labour market - at Nomenclature of Territorial Units for Statistics (NUTS) 2 level - is based on the micro-data of the Greek LFS. The access to the individual anonymized records of the Greek LFS was not allowed to researchers until the summer of 2005, due to the Data Protection Act.

The article starts discussing the relation between unemployment and level of education in the EU, as well as the impact of training programmes on the employment prospects of individuals in the EU and the rest of the OECD according to a series of studies. We also discuss the vocational training policies for the unemployed in Greece. Then, we refer to the macroeconomic indicators of the examined areas, discuss the limitations of the research working with Greek LFS micro-data and follow a logistic regression for the years 1994, 2000 and 2006 - based on micro-data of the Greek LFS for the three regions under study. The article concludes with the impact of the socio- 
economic variables used on employment probability in the examined regions.

\section{Unemployment, education and skills in Greece and the rest of the EU}

\subsection{Tertiary education studies in Greece}

In Greece, like in other EU member states, the number of higher education entrants has expanded substantially, since the number of new students in Universities and Technological Educational Institutions (TEI) rose from 21,642 in 1980 to 40,840 in 1994 and to 82,225 in 2000 (Ministry of Education, 2008). The expansion in the number of entrants and the huge fall in the number of school leavers has brought Greece into the group of countries with the highest enrolment rates (Katsikas and Panagiotidis, 2011).

There is an extensive literature in Greece concerning the equality of opportunities in accessing higher education. A number of authors found that candidates with more educated parents and coming from higher socio-economic background appear higher probabilities of tertiary education entry (see Chryssakis, 1991; Chryssakis and Soulis, 2001; Katsikas and Kavvadias, 1994; Kiridis, 1997). However, other studies (Papas and Psacharopoulos, 1991; Patrinos, 1992; Psacharopoulos and Tassoulas 2004; Tsakloglou and Cholezas, 2005) assert the opposite. Katsikas and Panagiotidis (2011) found no evidence that students' socio-economic background can explain students' differences in the length of studies, and also that the time required by a student to complete studies is relevant only for the students engaged in full-time jobs; namely, the tertiary education system in Greece does not seem to be helpful to the working students.

\subsection{Educational level and unemployment in the EU}

Table 1 gives unemployment rates by qualification in different EU countries according to Eurostat data. The differences were enormous. There are only a few countries where this inverse relation between unemployment and qualification did not exist.

In Greece and Portugal unemployment among people on ISCED (International Standard Classification of Education) 3 level (Lyceum) was higher than among the less qualified, but not among the University graduates (ISCED 5-7); in Italy and Luxembourg, unemployment rates among the highly qualified (ISCED 5-7, University) exceeded those of people with intermediate qualifications.

Looking at the long-term unemployment (LTU) of different skill levels, we again find that intermediate and higher educated people were less affected. This is true for the whole Union except Spain and Greece, where LTU was higher on ISCED levels 3 and 5-7 compared to levels 0-2, for Italy where LTU was the highest on ISCED 3 level, and for 
Luxembourg and Portugal where the ratios of ISCED levels 0-2 and 3 were equal (Eurostat, Education and Employment Prospects, 1995).

Table 1: Unemployment rates by level of educational attainment, 25-29 years old; EU 1994

\begin{tabular}{|l|c|c|c|}
\hline Country & ${\text { ISCED } 0-2^{\mathrm{c}}}^{\mathrm{a}}$ & ISCED $^{\mathrm{b}}$ & ISCED 5-7 $^{\mathrm{a}}$ \\
\hline BEL & 12.5 & 7.5 & 3.7 \\
\hline DEN & 12.6 & 8.3 & 4.6 \\
\hline GER & 14.8 & 8.9 & 5.3 \\
\hline GRE & 6.2 & 8.3 & 5.3 \\
\hline ESP & 22.4 & 20.0 & 15.1 \\
\hline FRA & 14.8 & 9.7 & 6.6 \\
\hline IRL & 21.0 & 9.1 & 5.3 \\
\hline ITA & 9.3 & 7.4 & 8.1 \\
\hline LUX & 3.7 & 1.9 & 2.4 \\
\hline NL & 12.6 & 7.7 & 5.5 \\
\hline POR & 6.1 & 6.4 & 2.4 \\
\hline UK & 11.2 & 7.9 & 4.1 \\
\hline EU-12 & $\mathbf{1 3 . 2}$ & $\mathbf{8 . 8}$ & $\mathbf{6 . 1}$ \\
\hline
\end{tabular}

Source: Eurostat: Education and Employment prospects, 1995.

a All first and higher degrees. All teaching, nursing qualifications. HNC/HND.

b 1 or more A-level passes, GNVQ 3 and equivalent, NVQ 3 and equivalent. Trade apprenticeship. GNVQ 2 or equivalent, NVQ2 or equivalent.

c ISCED 2: 1 or more O-level/ GCSE passes, 1 or more CSE passes. All other qualifications. ISCED 0-1: No qualifications.

\subsection{Training evaluation in Europe and Greece}

\subsubsection{Findings on European training programmes' evaluation}

Up-to-date evaluation studies point to minor impacts of European training policies and they are most likely less significant and not always as positive as those responsible for designing them had wished. Although the cross-national figures show a few positive results from programmes, it is impossible to disregard the more negative results. The findings allow us to conclude that training programmes seem to have some positive effects on employment and no effects on earnings. Moreover, effects diminish over time. The negative effects reported by several evaluations can be explained, on the one hand by a locking-in effect, and on the other 
by the fact that some participants seem to enrol in training merely in order to collect unemployment insurance benefits (Cueto and Mato, 2009). The conclusions based on the recent studies are somewhat similar to those of Heckman et al. (1999) and Stanley et al. (1999) for the U.S.

In spite of being restricted to only a small number of nations, micro-economic studies of effect evaluations, based on both cross-sectional and longitudinal data, indicate that some programmes have managed to noticeably better employment prospects for those taking part. On the other hand, the findings include a number of programmes which appear to have had almost no effect. Programmes with fairly specific targeting have managed positive results and this may be due to the fact that these programmes usually take account of individual requirements. However, a number of programmes that were most widely targeted have had little impact (see OECD, 1993; Torp, 1994; Calmfors and Skedinger, 1995; Jackman, 1995; Bjorklund and Regner, 1996; Fay, 1996; Zweimuller and Winter-Ebmer, 1996; Cockx et al., 1998; Kluve et al., 1999; Brodaty et al., 2001; Kluve and Schmidt, 2002; Regner, 2002; Cockx, 2003; Hamalainen and Ollikainen, 2004; Rosholm and Svarer, 2004; Albrecht et al., 2005; Arellano, 2005; Cavaco et al., 2005; Malmberg-Heimonen and Vuori, 2005; Stenberg, 2005; Winter-Ebmer, 2006; Biewen et al., 2007; Lechner et al., 2007; Meadows and Metcalf, 2008; Rosholm and Skipper, 2009; Kluve, 2010). Lastly, to establish the ways in which programmes can be made better more research is necessary.

\subsubsection{Vocational training policies for the unemployed in Greece}

The situation in Greece is complicated with low level of investments to training programmes compared to the rest of the EU, and weak interconnection among targeting of training programmes and needs of labour market.

The structure of expenditures for "active" interventions in 1997 shows that the level of expenditures in Greece (0.35\%), as a percentage of the GDP, is behind that of the EU15 average $(1.13 \%)$ concerning all specific interventions, with the exception of "measures for the young" (youth vocational education and training, etc. $-0.10 \%$ ) which are comparable to the European average $(0.13 \%)$. Furthermore, there is an extremely low level of expenditures on the training of adults $(0.06 \%$ for Greece in comparison to 0.29\% for the EU-15) - (OECD, Employment Outlook, 1999).

The system of continuing vocational training (CVT) in Greece was developed mainly due to its incorporation in Community funding programmes (Iliades, 1995; Chletsos, 1998; Papakonstantinou, 1998). Policies concerned with training and retraining for the unemployed have been confined to continuing training programmes. Vocational training programmes for the unemployed were unconnected with employment policies 
(Gravaris, 1991, p. 37; Christodoulakis and Kalyvitis, 1995; Balourdos and Chryssakis, 1998; Economic and Social Committee of Greece, 1998). This is reflected in the fact that the unemployment rate for those (20-29 years old) with complementary vocational training in Greece was 20\%, compared to $14 \%$ for those with only compulsory schooling; the corresponding figures for the EU were $11.5 \%$ and $23.5 \%$ (see Table 2).

Particularly with regard to training programmes for the unemployed in Greece, the method of identifying skills requirements, on the basis of which the programmes were offered, was wholly inadequate. It was based on changes in labour force categories derived from the LFS, on estimates of the impact of investment programmes on employment (where these existed or where such estimates were possible) and on Job Market Surveys. These last record shortages of skills on the basis of company estimates of their own shortages, which were often inaccurate or did not correspond to the capacity of the firms to utilise the skills demanded (Linardos-Rylmon, 1998).

Table 2: Unemployment rates among young people (20-29) with basic education and those with supplementary vocational education and training (EU - 1995 figures)

\begin{tabular}{|l|c|c|}
\hline \multicolumn{1}{|c|}{ Countries } & Basic Education & $\begin{array}{c}\text { Basic Education Plus Supplementary } \\
\text { Vocational Education / Training }\end{array}$ \\
\hline EU-14 & $\mathbf{2 3 . 5}$ & $\mathbf{1 1 . 5}$ \\
\hline Belgium & 24.3 & 19.7 \\
\hline Denmark & 17.7 & 8.5 \\
\hline Germany & 16.2 & 7.6 \\
\hline Greece & 14.3 & 20.0 \\
\hline Spain & 33.9 & 34.9 \\
\hline France & 30.0 & 17.1 \\
\hline Italy & 22.2 & 15.9 \\
\hline Luxembourg & 5.7 & $:$ \\
\hline Netherlands & 14.8 & 7.2 \\
\hline Austria & $:$ & 4.0 \\
\hline Portugal & 11.2 & 16.2 \\
\hline Finland & 35.4 & 23.6 \\
\hline Sweden & 21.7 & 10.0 \\
\hline UK & 18.5 & \\
\hline
\end{tabular}

Ireland - No figures available

$:=$ Data unreliable

Source: Eurostat (as quoted in Economic and Social Committee of Greece, 1998, p.31). 
Review of Economic Analysis 4 (2012) 224-246

\section{Macroeconomic data of the examined areas}

The Region of Central Macedonia (RCM) is the largest of Greece $\left(19,147 \mathrm{~km}^{2}-14.5 \%\right.$ of the country's surface) and is situated in the centre of Northern Greece. The RCM consists of seven NUTS-3 areas (Thessaloniki, Serres, Chalkidiki, Imathia, Pella, Kilkis and Pieria) and is the second largest Greek region in terms of population (about 1.7 million inhabitants according to 1991 census). Also, the major urban centre and capital of Central Macedonia is Thessaloniki, which is the second most important Greek city. According to 1991 census the population of the Thessaloniki Area was about 750,000 inhabitants, whereas that of the county of Thessaloniki was approximately 945,000 inhabitants. The main industries were textiles, plastic-chemicals, food-beverages and clothing. In 2003, the region's per capita GDP (PPS) was 17,110 euro ( $83 \%$ of the EU-25 average), whereas Thessaloniki and Chalkidiki were the richest NUTS-3 areas of the region having a GDP per head equal to $90.3 \%$ and $89.5 \%$ correspondingly of the EU-25 mean. In 2003 the region produced $17.6 \%$ of the country's GDP (the second largest contributor after Attica) - 18\% of the national agricultural produce (first in the country), $20 \%$ of the manufacturing production (second in the country) and $18 \%$ of services (second in the country). The unemployment rate in the RCM was $9.2 \%$ in 1992 and increased to $11.5 \%$ in 2002 (source: www.economics.gr).

The Region of Western Macedonia contains the counties of Grevena, Kastoria, Kozani and Florina. With Kozani at its centre, the region is inhabited by $2.8 \%$ of the country's total population (303.857 inhabitants in 2005). Between the census of 1991 and 2001 the population rose by $2.9 \%$, a rise lower than the national mean $(6.9 \%)$. The per capita GDP was 14,300 euro in 2003 (the region came fourth out of the 13 regions in the country in 2001 - the regional GDP was $82.8 \%$ of the EU-25 average). Western Macedonia produces $2.9 \%$ of the country's GDP $-5.4 \%$ of the national agricultural produce, $0.9 \%$ of the manufacturing production and $2.2 \%$ of services. Fourteen percent of the region's gross product comes from the production of electricity and $8 \%$ from mined lignite. The region accounted for $6 \%$ of the country's cultivated land, $12 \%$ of total wheat production and $12 \%$ of apple production, in 2001 . Businesses based in the area in 2001 accounted for only $0.8 \%$ of the turnover of the manufacturing and construction sector nationally, and $1.2 \%$ of trade. Unemployment in the region was $15.9 \%$ in 2001 , the highest rate in the country (source: www.economics.gr).

The Region of Eastern Macedonia and Thrace contains the counties of Drama, Evros, Kavala, Xanthi and Rodopi. With Komotini as its centre, the population size of the region was 561.838 in 1998 (5.3\% of the country's total population). Between the census of 1991 and 2001 its population rose by 7.1\%. The per capita GDP was 10,500 euro in 2003 (the poorest region in the country in 2001). The area produces $4.4 \%$ of the national GDP - $10 \%$ of the country's agricultural production, $4.3 \%$ of manufacturing and 
3.5\% of services (1998). Eastern Macedonia and Thrace accounted for $11 \%$ of the country's cultivated land, $14 \%$ of total cotton production, $24 \%$ of wheat production, $12 \%$ of potato production and $11.6 \%$ of tobacco production, in 2001. Businesses based in the region in 2001 accounted for $2.7 \%$ of the turnover of the national manufacturing and construction sector, and $2.9 \%$ of trade. Unemployment in the region was $9.3 \%$ of the workforce in 2001 (10.5\% for Greece as a whole) - (source: www.economics.gr).

\section{Econometric model: Logistic regression for unemployment}

\subsection{The logistic regression based on the micro-data of the Greek LFS}

European Community Household Panel Survey (ECHPS) and Survey on Income and Living Conditions (SILC) data have been designed for the country as a whole in the case of Greece, so we cannot really work at regional level. Also, individual census records do not exist in Greece, like e.g. in Denmark, so the only way is to base our research on the LFS micro-data.

The questionnaire of the Greek LFS was greatly modified in 1992 and 1998. The originality of this research is that we use individual anonymised records (micro-data) of the 1994, 2000 and 2006 LFS for both employed and unemployed; the LFS sample is equal to $1.5 \%$ of the total population of each area. Since 1998 LFS has been conducted four times a year - instead of once per year until 1997 - with a sample of about 80,000 records for the whole country ( $0.7 \%$ of the total population) in each of the four quarters (ESYE).

Tables $3 A$ and $3 B$ show the numbers of records eligible for analysis in the LFS samples of all three regions under examination in 1994, 2000 and 2006. The reason we choose these years is because 1994 is the first year of the CSF-2, 2000 counts exactly one year after the end of the CSF-2, whereas 2006 is the last year of the CSF-3. Apart from the system missing records, following the limitation of age (15-64 years old) and removing the non-active population, we ended with the following numbers of records eligible for analysis in each region (in the spring and early summer, namely from the 14 th to 26 th week of the year).

The basic aim of the econometric analysis is to test the impact that various social and demographic characteristics had on people's job prospects in the three Northern Greek regions, during the implementation of the CSF-2 (1994-99) and the CSF-3 (2000-06), accounting for variables such as age, gender, marital status, area of residence, immigrant status, level of education, participation in training programs. We use a logistic regression model. The dependent variable takes two possible values (employed versus unemployed). The explanatory variables (seven for 2006, nine for 2000 and eight for 1994) are the participation in training courses [non-available in 2006, with five 
categories including the four types of training completed (apprenticeship, intra-firm training, CVT and popular training) and non-participation in training courses as the reference category, plus number of years since the interviewee has finished the training program(s) - available only in 2000], (six) levels of education, gender, age group (four categories), marital status, residence location (Thessaloniki area, the rest of urban areas, semi-urban areas and rural areas), registered in the Manpower Employment Organization (OAED) and immigrant status.

Table 3 A: Descriptive Statistics (Absolute Numbers)

\begin{tabular}{|c|c|c|c|c|c|c|c|c|c|}
\hline & $\begin{array}{l}\text { West } \\
\text { Mac. } \\
\text { (1994) }\end{array}$ & $\begin{array}{c}\text { Central } \\
\text { Mac. } \\
(1994)\end{array}$ & $\begin{array}{c}\text { East Mac. } \\
\text { \& Thrace } \\
\text { (1994) }\end{array}$ & $\begin{array}{l}\text { West } \\
\text { Mac. } \\
\text { (2000) }\end{array}$ & $\begin{array}{c}\text { Central } \\
\text { Mac. } \\
(2000)\end{array}$ & $\begin{array}{c}\text { East Mac. } \\
\text { \& Thrace } \\
(2000)\end{array}$ & $\begin{array}{l}\text { West } \\
\text { Mac. } \\
(2006)\end{array}$ & $\begin{array}{c}\text { Central } \\
\text { Mac. } \\
(2006)\end{array}$ & $\begin{array}{c}\text { East Mac. } \\
\text { \& Thrace } \\
(2006)\end{array}$ \\
\hline Total cases & 3500 & 9543 & 3510 & 2178 & 5565 & 1089 & 2157 & 4984 & 946 \\
\hline Employed & 3213 & 8694 & 3170 & 1984 & 4953 & 923 & 1922 & 4506 & 811 \\
\hline Unemployed & 287 & 849 & 340 & 194 & 612 & 166 & 235 & 478 & 135 \\
\hline Males & 2055 & 5964 & 2292 & 1248 & 3339 & 670 & 1238 & 2856 & 561 \\
\hline Females & 1446 & 3579 & 1218 & 930 & 2226 & 419 & 919 & 2128 & 385 \\
\hline Married or divorced or widows & 2755 & 7215 & 2689 & 1673 & 3862 & 798 & 1549 & 3479 & 670 \\
\hline Aged 15-24 & 494 & 1145 & 404 & 281 & 679 & 109 & 186 & 429 & 74 \\
\hline Aged 25-34 & 809 & 2577 & 913 & 536 & 1547 & 322 & 546 & 1276 & 229 \\
\hline Aged 35-44 & 819 & 2433 & 927 & 514 & 1480 & 289 & 632 & 1495 & 294 \\
\hline Aged 45-64 & 1379 & 3397 & 1271 & 847 & 1859 & 369 & 794 & 1779 & 349 \\
\hline MSc or PhD holders & 4 & 19 & n.a. & 2 & 22 & n.a. & 4 & 75 & 3 \\
\hline University graduates & 270 & 1279 & 362 & 200 & 879 & 125 & 248 & 892 & 132 \\
\hline TEl graduates & 140 & 611 & 172 & 203 & 696 & 138 & 233 & 773 & 121 \\
\hline 12 years of schooling & 655 & 2586 & 786 & 492 & 1775 & 291 & 638 & 1675 & 319 \\
\hline 9 years compulsory education & 301 & 887 & 400 & 194 & 590 & 132 & 231 & 573 & 123 \\
\hline Primary school graduates and below & 2132 & 4151 & 1794 & 1087 & 1603 & 403 & 800 & 997 & 248 \\
\hline Thessaloniki area & n.a. & 4724 & n.a. & n.a. & 3367 & n.a. & n.a. & 3040 & n.a. \\
\hline Rest of urban areas (RCM) or urban areas & 1428 & 1260 & 1278 & 989 & 651 & 461 & 1053 & 713 & 379 \\
\hline Semi-urban areas & 574 & 1393 & 562 & 362 & 634 & 161 & 324 & 633 & 183 \\
\hline Rural areas & 1498 & 2166 & 1671 & 828 & 907 & 467 & 781 & 593 & 373 \\
\hline Apprenticeship & 4 & 38 & 35 & 52 & 262 & 102 & n.a. & n.a. & n.a. \\
\hline Intra-firm training & n.a. & 10 & 7 & 2 & 22 & 8 & n.a. & n.a. & n.a. \\
\hline CVT & 4 & 29 & 18 & 48 & 67 & 54 & n.a. & n.a. & n.a. \\
\hline Popular training & n.a. & 0 & n.a. & 2 & 11 & 7 & n.a. & n.a. & n.a. \\
\hline Time of training completion & n.a. & n.a. & n.a. & 13 & 50 & 8 & n.a. & n.a. & n.a. \\
\hline Registered in OAED & 98 & 172 & 116 & 139 & 289 & 151 & 192 & 384 & 149 \\
\hline Non-immigrants & 3476 & 9428 & 3496 & 2150 & 5437 & 1081 & 2118 & 4715 & 933 \\
\hline
\end{tabular}

We tried numerous regressions with different variables in order to end up with the chosen variables. The base (or reference) categories are those that appear in the Tables 4, 5 and 6 
with empty cells and with which the rest of the corresponding variables are compared. The reference categories are chosen so as to match the needs of the research.

The variable "participation in the past in training course(s)" first appeared in the 1992 questionnaire; it means that the interviewee had completed one or more training courses. This is also an indication of the attitude towards training in Greece at the beginning of the 1990s. The duration of apprenticeship and intra-firm training has to be at least one year according to the 1994 questionnaires of the Greek LFS. However, in 2000 all training questions refer only to those who completed a training course lasting at least six months. Also, the question "how many years before the survey has the interviewee finished the training programme(s)?" exists only in 2000. The term "popular training" (laiki epimorphosi in Greek) means training courses intended mainly for elderly people independently of their educational level, where the curriculum includes largely courses of general knowledge.

Table 3 B: Descriptive Statistics (Percentages)

\begin{tabular}{|c|c|c|c|c|c|c|c|c|c|}
\hline & $\begin{array}{l}\text { West } \\
\text { Mac. } \\
(1994) \\
\end{array}$ & $\begin{array}{c}\text { Central } \\
\text { Mac. } \\
(1994) \\
\end{array}$ & $\begin{array}{c}\text { East Mac. } \\
\text { \& Thrace } \\
(1994)\end{array}$ & $\begin{array}{l}\text { West } \\
\text { Mac. } \\
(2000) \\
\end{array}$ & $\begin{array}{c}\text { Central } \\
\text { Mac. } \\
(2000) \\
\end{array}$ & $\begin{array}{c}\text { East Mac. } \\
\& \text { Thrace } \\
(2000)\end{array}$ & $\begin{array}{l}\text { West } \\
\text { Mac. } \\
(2006) \\
\end{array}$ & $\begin{array}{c}\text { Central } \\
\text { Mac. } \\
(2006) \\
\end{array}$ & $\begin{array}{c}\text { East Mac. } \\
\text { \& Thrace } \\
(2006)\end{array}$ \\
\hline Total cases & 3500 & 9543 & 3510 & 2178 & 5565 & 1089 & 2157 & 4984 & 946 \\
\hline Employed & $91.80 \%$ & $91.10 \%$ & $90.30 \%$ & $91.10 \%$ & $89.00 \%$ & $84.80 \%$ & $89.10 \%$ & $90.40 \%$ & $85.70 \%$ \\
\hline Unemployed & $8.20 \%$ & $8.90 \%$ & $9.70 \%$ & $8.90 \%$ & $11.00 \%$ & $15.20 \%$ & $10.90 \%$ & $9.60 \%$ & $14.30 \%$ \\
\hline Males & $58.70 \%$ & $62.50 \%$ & $65.30 \%$ & $57.30 \%$ & $60.00 \%$ & $61.50 \%$ & $57.40 \%$ & $57.30 \%$ & $59.30 \%$ \\
\hline Females & $41.30 \%$ & $37.50 \%$ & $34.70 \%$ & $42.70 \%$ & $40.00 \%$ & $38.50 \%$ & $42.60 \%$ & $42.70 \%$ & $40.70 \%$ \\
\hline Married or divorced or widows & $78.70 \%$ & $75.60 \%$ & $76.60 \%$ & $76.80 \%$ & $69.40 \%$ & $73.30 \%$ & $71.80 \%$ & $69.80 \%$ & $70.80 \%$ \\
\hline Aged 15-24 & $14.10 \%$ & $12.00 \%$ & $11.50 \%$ & $12.90 \%$ & $12.20 \%$ & $10.00 \%$ & $8.60 \%$ & $8.60 \%$ & $7.80 \%$ \\
\hline Aged 25-34 & $23.10 \%$ & $27.00 \%$ & $26.00 \%$ & $24.60 \%$ & $27.80 \%$ & $29.60 \%$ & $25.30 \%$ & $25.60 \%$ & $24.20 \%$ \\
\hline Aged 35-44 & $23.40 \%$ & $25.50 \%$ & $26.40 \%$ & $23.60 \%$ & $26.60 \%$ & $26.50 \%$ & $29.30 \%$ & $30.00 \%$ & $31.10 \%$ \\
\hline Aged 45-64 & $39.40 \%$ & $35.60 \%$ & $36.20 \%$ & $38.90 \%$ & $33.40 \%$ & $33.90 \%$ & $36.80 \%$ & $35.70 \%$ & $36.90 \%$ \\
\hline MSc or PhD holders & $0.10 \%$ & $0.20 \%$ & n.a. & $0.10 \%$ & $0.40 \%$ & n.a. & $0.20 \%$ & $1.50 \%$ & $0.30 \%$ \\
\hline University graduates & $7.70 \%$ & $13.40 \%$ & $10.30 \%$ & $9.20 \%$ & $15.80 \%$ & $11.50 \%$ & $11.50 \%$ & $17.90 \%$ & $14.00 \%$ \\
\hline TEI graduates & $4.00 \%$ & $6.40 \%$ & $4.90 \%$ & $9.30 \%$ & $12.50 \%$ & $12.70 \%$ & $10.80 \%$ & $15.50 \%$ & $12.80 \%$ \\
\hline 12 years of schooling & $18.70 \%$ & $27.10 \%$ & $22.40 \%$ & $22.60 \%$ & $31.90 \%$ & $26.70 \%$ & $29.60 \%$ & $33.60 \%$ & $33.70 \%$ \\
\hline 9 years compulsory education & $8.60 \%$ & $9.30 \%$ & $11.40 \%$ & $8.90 \%$ & $10.60 \%$ & $12.10 \%$ & $10.70 \%$ & $11.50 \%$ & $13.00 \%$ \\
\hline Primary school graduates and below & $60.90 \%$ & $43.50 \%$ & $51.10 \%$ & $49.90 \%$ & $28.80 \%$ & $37.00 \%$ & $37.10 \%$ & $20.00 \%$ & $26.20 \%$ \\
\hline Thessaloniki area & n.a & $49.50 \%$ & n.a & n.a & $60.50 \%$ & n.a & n.a & $61.00 \%$ & n.a \\
\hline Rest of urban areas (RCM) or urban areas & $40.80 \%$ & $13.20 \%$ & $36.40 \%$ & $45.40 \%$ & $11.70 \%$ & $42.30 \%$ & $48.80 \%$ & $14.30 \%$ & $40.10 \%$ \\
\hline Semi-urban areas & $16.40 \%$ & $14.60 \%$ & $16.00 \%$ & $16.60 \%$ & $11.40 \%$ & $14.80 \%$ & $15.00 \%$ & $12.70 \%$ & $19.30 \%$ \\
\hline Rural areas & $42.80 \%$ & $22.70 \%$ & $47.60 \%$ & $38.00 \%$ & $16.30 \%$ & $42.90 \%$ & $36.20 \%$ & $11.90 \%$ & $39.40 \%$ \\
\hline Apprenticeship & $0.10 \%$ & $0.40 \%$ & $1.00 \%$ & $2.40 \%$ & $4.70 \%$ & $9.40 \%$ & n.a & n.a & n.a \\
\hline Intra-firm training & n.a & $0.10 \%$ & $0.20 \%$ & $0.10 \%$ & $0.40 \%$ & $0.70 \%$ & n.a & n.a & n.a \\
\hline CVT & $0.10 \%$ & $0.30 \%$ & $0.50 \%$ & $2.20 \%$ & $1.20 \%$ & $5.00 \%$ & n.a & n.a & n.a \\
\hline Popular training & n.a & $0.00 \%$ & n.a & $0.10 \%$ & $0.20 \%$ & $0.60 \%$ & n.a & n.a & n.a \\
\hline Time of training completion & n.a & n.a & n.a & $0.60 \%$ & $0.90 \%$ & $0.70 \%$ & n.a & n.a & n.a \\
\hline Registered in OAED & $2.80 \%$ & $1.80 \%$ & $3.30 \%$ & $6.40 \%$ & $5.20 \%$ & $13.90 \%$ & $8.90 \%$ & $7.70 \%$ & $15.80 \%$ \\
\hline Non-immigrants & $99.30 \%$ & $98.80 \%$ & $99.60 \%$ & $98.70 \%$ & $97.70 \%$ & $99.30 \%$ & $98.20 \%$ & $94.60 \%$ & $98.60 \%$ \\
\hline
\end{tabular}


Due to data limitations, we cannot explore the impact that the duration of courses, thematic fields, number of participants, duration of unemployment period of the trainees have on unemployment. Another limitation of the research is that the data available are cross-sectional rather than longitudinal and therefore we cannot study any population changes across time.

The descriptive statistics for all three regions are summarised in Tables $3 \mathrm{~A}$ and $3 \mathrm{~B}$ (see separate file). The Tables 4, 5 and 6 present the estimated coefficients (B) and their standard errors (S.E.) of each explanatory variable in the logistic regression for unemployment. The column "Sig." (level of statistical significance or $p$ value) corresponds to the probability of the rejection area, so coefficients with a value not higher than 0.05 are highly and significantly different from zero.

\subsection{Analysis of the results for Central Macedonia}

Table 4 presents the results of the logistic regression in the RCM for 1994, 2000 and 2006. In 1994, women, non-married individuals, people in the age group 15-24 years old, people who lived either in the area of Thessaloniki, the rest of urban areas or semi-urban areas were more likely to be unemployed than men, married people, people in the age between 25 to 64 and those in rural areas. The results are in accordance with the family strategies and the gender roles in traditional families in some areas of the region, as well as to the unequal opportunities and discrimination against women by companies. The gender differences could also be attributed to the fact that women often join the labour market earlier. Compulsory military service and further education (not a likely explanation anymore) were the major reasons for men's delay in entering the labour market. Extended family protection, with a view to preparation for entry into the labour market, applies to both sexes, of course. The effect of urbanization level can be explained since in the Greek agrarian sector unemployment was not properly counted, because hidden unemployment is quite high.

In addition, for 1994 university graduates were more likely to be employed compared to primary school graduates (other differences were not found significant). The variable "immigrant status" was found to be statistically significant in the RCM only for 1994, namely that year the immigrants were more likely to be employed than the Greeks. Also, in all years, people who were registered in OAED were more likely to be unemployed.

For 2000 the only differences with 1994 are those of semi-urban areas (statistically non-significant in 2000) and the educational category "high-school graduates" (more likely to be unemployed than university graduates). The 1994 and 2000 findings confirm the human capital theory that the more education one receives the more chances he has on employment. The results for 2006 differ from 1994 and 2000 in MSc 
or PhD holders (more likely to be unemployed than university graduates), and also that all three urbanization categories are statistically non-significant.

None of the four types of training programmes seemed to reduce the odds of unemployment for 1994 and 2000. Namely, all training variables were found to be statistically non-significant; this means that the results of training variables are not compatible with the human capital theory, so the more trained a person did not affect his chances of finding a job, in Central Macedonia, during this period. Also, the variable on time of training completion (namely, how many years before the survey has the interviewee finished the training program(s) was found to be statistically nonsignificant. The results of the econometric analysis confirm the conclusions of the various studies for the limited impact of vocational training in Greece (see section 2.3.2).

TABLE 4 - Results for Central Macedonia

\begin{tabular}{|c|c|c|c|c|c|c|c|c|c|c|c|c|}
\hline \multirow[b]{2}{*}{ Variables } & \multicolumn{4}{|c|}{1994} & \multicolumn{4}{|c|}{2000} & \multicolumn{4}{|c|}{2006} \\
\hline & $b_{k}$ & s.e. & Sig. & $\operatorname{Exp}\left(b_{k}\right)$ & $b_{k}$ & s.e. & Sig. & $\operatorname{Exp}\left(b_{k}\right)$ & $b_{k}$ & s.e. & Sig. & $\operatorname{Exp}\left(b_{k}\right)$ \\
\hline Gender & 0.858 & 0.082 & 0 & 2.36 & 1.127 & 0.107 & 0 & 3.086 & 1.001 & 0.15 & 0 & 2.721 \\
\hline Marital status & -1.039 & 0.105 & 0 & 0.354 & -0.904 & 0.139 & 0 & 0.405 & -0.63 & 0.189 & 0.001 & 0.533 \\
\hline Aged 15-24 & - & - & - & - & - & - & - & - & - & - & - & - \\
\hline Aged 25-34 & -0.921 & 0.106 & 0 & 0.398 & -0.484 & 0.142 & 0.001 & 0.616 & -0.917 & 0.22 & 0 & 0.4 \\
\hline Aged 35-44 & -1.493 & 0.147 & 0 & 0.225 & -0.894 & 0.188 & 0 & 0.409 & -1.084 & 0.253 & 0 & 0.338 \\
\hline Aged 45-64 & -1.634 & 0.157 & 0 & 0.195 & -1.284 & 0.208 & 0 & 0.277 & -1.328 & 0.273 & 0 & 0.265 \\
\hline MSc or PhD holders & -0.096 & 1.072 & 0.929 & 0.908 & -2.584 & 4.296 & 0.548 & 0.076 & 1.278 & 0.476 & 0.007 & 3.589 \\
\hline University graduates & - & - & - & - & - & - & - & - & - & - & - & - \\
\hline TEI graduates & 0.132 & 0.179 & 0.462 & 1.141 & 0.076 & 0.21 & 0.718 & 1.079 & 0.252 & 0.262 & 0.336 & 1.286 \\
\hline 12 years of schooling & 0.243 & 0.138 & 0.078 & 1.275 & 0.571 & 0.17 & 0.001 & 1.769 & 0.36 & 0.231 & 0.12 & 1.434 \\
\hline 9 years compulsory education & 0.306 & 0.167 & 0.066 & 1.358 & 0.436 & 0.218 & 0.046 & 1.546 & 0.555 & 0.282 & 0.049 & 1.742 \\
\hline Primary school graduates and below & 0.431 & 0.147 & 0.003 & 1.539 & 0.888 & 0.194 & 0 & 2.431 & 0.836 & 0.258 & 0.001 & 2.307 \\
\hline Thessaloniki area & 0.967 & 0.129 & 0 & 2.63 & 0.5 & 0.166 & 0.003 & 1.648 & -0.095 & 0.226 & 0.674 & 0.909 \\
\hline Rest of urban areas & 1.18 & 0.151 & 0 & 3.255 & 0.828 & 0.199 & 0 & 2.288 & -0.168 & 0.212 & 0.427 & 0.845 \\
\hline Semi-urban areas & 0.395 & 0.163 & 0.016 & 1.484 & 0.053 & 0.22 & 0.811 & 1.054 & -0.341 & 0.232 & 0.141 & 0.711 \\
\hline Rural areas & - & - & - & - & - & - & - & - & - & - & - & - \\
\hline Apprenticeship & -0.61 & 0.597 & 0.307 & 0.543 & 0.187 & 0.25 & 0.456 & 1.205 & n.a. & n.a. & n.a. & n.a. \\
\hline Intra-firm training & 1.41 & 0.852 & 0.098 & 4.096 & 0.102 & 0.71 & 0.886 & 1.107 & n.a. & n.a. & n.a. & n.a. \\
\hline CVT & 0.835 & 0.621 & 0.178 & 2.305 & 0.119 & 0.425 & 0.779 & 1.127 & n.a. & n.a. & n.a. & n.a. \\
\hline Popular training & 1.903 & 1.258 & 0.13 & 6.709 & -1.458 & 1.119 & 0.192 & 0.233 & n.a. & n.a. & n.a. & n.a. \\
\hline Non-participation in training & - & - & - & - & - & - & - & - & n.a. & n.a. & n.a. & n.a. \\
\hline Time of training completion & n.a. & n.a. & n.a. & n.a. & -0.234 & 0.451 & 0.604 & 0.792 & n.a. & n.a. & n.a. & n.a. \\
\hline Registered in OAED & 3.279 & 0.181 & 0 & 26.554 & 3.462 & 0.159 & 0 & 31.873 & 4.835 & 0.167 & 0 & 125.786 \\
\hline Non-immigrants & 1.642 & 0.241 & 0 & 5.168 & -0.142 & 0.306 & 0.644 & 0.868 & -0.386 & 0.272 & 0.156 & 0.68 \\
\hline Constant & -2.305 & 0.188 & 0 & 0.1 & -2.645 & 0.392 & 0 & 0.071 & -2.505 & 0.363 & 0 & 0.082 \\
\hline
\end{tabular}




\subsection{Analysis of the results for Western Macedonia}

Table 5 presents the results of the logistic regression in Western Macedonia for 1994, 2000 and 2006. In 1994, women, people in the age group 15-24 years old, people who lived either in the area of Thessaloniki, the rest of urban areas or semi-urban areas were more likely to be unemployed than men, married people, people in the age between 25 to 64 and those in rural areas. The results for gender and level of urbanization are like in Central Macedonia.

TABLE 5 - Results for Western Macedonia

\begin{tabular}{|c|c|c|c|c|c|c|c|c|c|c|c|c|}
\hline \multirow[b]{2}{*}{ Variables } & \multicolumn{4}{|c|}{1994} & \multicolumn{4}{|c|}{2000} & \multicolumn{4}{|c|}{2006} \\
\hline & $b_{k}$ & s.e. & Sig. & $\operatorname{Exp}\left(b_{k}\right)$ & $b_{k}$ & s.e. & Sig. & $\operatorname{Exp}\left(b_{k}\right)$ & $b_{k}$ & s.e. & Sig. & $\operatorname{Exp}\left(b_{k}\right)$ \\
\hline Gender & 0.822 & 0.146 & 0 & 2.274 & 0.7 & 0.19 & 0 & 2.014 & 0.398 & 0.235 & 0.091 & 1.489 \\
\hline Mlarital status & -0.231 & 0.192 & 0.229 & 0.793 & -0.599 & 0.255 & 0.019 & 0.55 & -0.104 & 0.313 & 0.739 & 0.901 \\
\hline Aged 15-24 & - & - & - & - & - & - & - & - & - & - & - & - \\
\hline Aged 25-34 & -0.825 & 0.202 & 0 & 0.438 & -0.294 & 0.28 & 0.294 & 0.745 & -1.26 & 0.36 & 0 & 0.284 \\
\hline Aged 35-44 & -1.515 & 0.252 & 0 & 0.22 & -0.756 & 0.344 & 0.028 & 0.469 & -1.962 & 0.419 & 0 & 0.141 \\
\hline Aged 45-64 & -1.745 & 0.263 & 0 & 0.175 & -0.976 & 0.346 & 0.005 & 0.377 & -1.862 & 0.423 & 0 & 0.155 \\
\hline MISc or PhD holders & -2.539 & 15.619 & 0.871 & 0.079 & -3.308 & 12.449 & 0.79 & 0.037 & 0.349 & 1.796 & 0.846 & 1.417 \\
\hline University graduates & - & - & - & - & - & - & - & - & - & - & - & - \\
\hline TEl graduates & 1.101 & 0.402 & 0.006 & 3.007 & -0.244 & 0.451 & 0.588 & 0.783 & 0.16 & 0.512 & 0.755 & 1.173 \\
\hline 12 years of schooling & 1.001 & 0.335 & 0.003 & 2.721 & 0.35 & 0.361 & 0.332 & 1.419 & 0.4 & 0.437 & 0.361 & 1.491 \\
\hline 9 years compulsory education & 1.248 & 0.364 & 0.001 & 3.482 & 0.022 & 0.445 & 0.96 & 1.022 & 0.486 & 0.511 & 0.341 & 1.627 \\
\hline Primary school graduates and & 0.769 & 0.344 & 0.026 & 2.159 & 0.832 & 0.374 & 0.026 & 2.298 & 0.585 & 0.482 & 0.225 & 1.794 \\
\hline Urban areas & 1.438 & 0.206 & 0 & 4.21 & 1.203 & 0.24 & 0 & 3.329 & 0.642 & 0.302 & 0.033 & 1.9 \\
\hline Semi-urban areas & 1.09 & 0.233 & 0 & 2.973 & 0.541 & 0.294 & 0.065 & 1.718 & 0.596 & 0.351 & 0.09 & 1.814 \\
\hline Rural areas & - & - & - & - & - & - & - & - & - & - & - & - \\
\hline Apprenticeship & -2.515 & 9.932 & 0.8 & 0.081 & -0.121 & 0.701 & 0.863 & 0.886 & n.a. & n.a. & n.a. & n.a. \\
\hline Intra-firm training & n.a. & n.a. & n.a. & n.a. & -2.47 & 15.7 & 0.875 & 0.085 & n.a. & n.a. & n.a. & n.a. \\
\hline CVT & 2.963 & 1.299 & 0.023 & 19.357 & 1.103 & 0.533 & 0.038 & 3.012 & n.a. & n.a. & n.a. & n.a. \\
\hline Popular training & n.a. & n.a. & n.a. & n.a. & -3.185 & 15.263 & 0.835 & 0.041 & n.a. & n.a. & n.a. & n.a. \\
\hline $\begin{array}{l}\text { Non-participation in training } \\
\text { course(s) }\end{array}$ & - & - & - & - & - & - & - & - & n.a. & n.a. & n.a. & n.a. \\
\hline Time of training completion & n.a. & n.a. & n.a. & n.a. & -0.516 & 0.992 & 0.603 & 0.597 & n.a. & n.a. & n.a. & n.a. \\
\hline Registered in OAED & 3.113 & 0.251 & 0 & 22.495 & 3.626 & 0.233 & 0 & 37.546 & 5.5 & 0.288 & 0 & 244.592 \\
\hline Non-immigrants & 2.641 & 0.518 & 0 & 14.033 & -1.059 & 0.597 & 0.076 & 0.347 & -1.359 & 0.565 & 0.016 & 0.257 \\
\hline Constant & -3.74 & 0.397 & 0 & 0.024 & -2.486 & 0.734 & 0.001 & 0.083 & -1.567 & 0.767 & 0.041 & 0.209 \\
\hline
\end{tabular}

In addition, for 1994 university graduates were more likely to be employed compared to all 
other educational categories (apart from postgraduates - non-significant). The variable "immigrant status" was found to be statistically significant in Western Macedonia only for 1994 (namely that year the immigrants were more likely to be employed than the Greeks), and 2006 (more likely to be unemployed than the native labour force). Also, in all years, people who were registered in OAED were more likely to be unemployed.

For 2000 the differences with 1994 are those of people aged 25-34 (statistically nonsignificant), non-married individuals (less likely to be employed than married - this variable is statistically significant only for 1994), semi-urban areas (statistically nonsignificant in 2000) and that the only statistically significant educational category is that of "primary school graduates" (more likely to be unemployed than university graduates). The 1994 and 2000 (in part) findings confirm the human capital theory that the more education one receives the more chances he has on employment. For 2006 all educational categories were found to be statistically non-significant and also the results of the urbanization categories are like in 2000.

None of the four types of training programs seemed to reduce the odds of unemployment for 1994 and 2000 (participation in CVT appears even worse prospects in the labour market than non-participation). Also, the variable on time of training completion was found to be statistically non-significant, like in the RCM. The results of the econometric analysis confirm the conclusions of the various studies for the limited impact of vocational training in Greece (see section 2.3.2), like in the RCM. However, since there is always the question of wages which we cannot examine, there is nothing incompatible with rational economic decision making in searching longer for a job, if the expected wage gain is sufficiently high.

\subsection{Analysis of the results for Eastern Macedonia and Thrace}

Table 6 presents the results of the logistic regression in Eastern Macedonia and Thrace for 1994, 2000 and 2006. In 1994, women, non-married individuals, people in the age group 1524 years old, people who lived in the urban areas were more likely to be unemployed than men, married people, people in the age between 25 to 64 and those in rural areas. The results for gender and level of urbanization are like the rest of the examined regions above.

In addition, for 1994 all educational categories were not found significant. None of the four types of training programs seemed to reduce the odds of unemployment for 1994. The variable "immigrant status" was found to be statistically significant in Eastern Macedonia and Thrace for all three years; however, for 1994 and 2006 the immigrants were more likely to be employed than the Greeks, whereas the opposite was in force for 2000. Also, in all years, people who were registered in OAED were more likely to be unemployed. 
For 2000 the only differences with 1994 (apart from the immigrant status) are those of marital status (statistically non-significant in 2000) and the training variables "apprenticeship" and "CVT" (less likely to be unemployed than the non-trainees). The results for these two types of training in Eastern Macedonia and Thrace are unique not only in comparison to the rest two of Northern Greek regions examined in this paper, but also in relation to other Greek NUTS-2 areas evaluated up to 1992 and the entire country evaluated up to 2006 (see, Rodokanakis and Tryfonidis, 2008 and 2009; Rodokanakis, 2009, 2010 and 2011, Rodokanakis and Vlachos, 2012). Only the 1994 results of the econometric analysis confirm the conclusions of the various studies for the limited impact of vocational training in Greece.

TABLE 6 - Results for Eastern Macedonia \& Thrace

\begin{tabular}{|c|c|c|c|c|c|c|c|c|c|c|c|c|}
\hline \multirow[b]{2}{*}{ Variables } & \multicolumn{4}{|c|}{1994} & \multicolumn{4}{|c|}{2000} & \multicolumn{4}{|c|}{2006} \\
\hline & $b_{k}$ & s.e. & Sig. & $\operatorname{Exp}\left(b_{k}\right)$ & $b_{k}$ & s.e. & Sig. & $\operatorname{Exp}\left(b_{k}\right)$ & $b_{k}$ & s.e. & Sig. & $\operatorname{Exp}\left(b_{k}\right)$ \\
\hline Gender & 1.01 & 0.141 & 0 & 2.745 & 1.089 & 0.246 & 0 & 2.972 & 0.897 & 0.272 & 0.001 & 2.451 \\
\hline Marital status & -0.827 & 0.177 & 0 & 0.437 & -0.15 & 0.308 & 0.627 & 0.861 & -0.099 & 0.364 & 0.785 & 0.905 \\
\hline Aged 15-24 & - & - & - & - & - & - & - & - & - & - & - & - \\
\hline Aged 25-34 & -1.111 & 0.176 & 0 & 0.329 & -1.537 & 0.374 & 0 & 0.215 & -0.84 & 0.487 & 0.085 & 0.43 .2 \\
\hline Aged 35-44 & -2.168 & 0.26 & 0 & 0.114 & -1.956 & 0.437 & 0 & 0.141 & -1.162 & 0.566 & 0.04 & $0.31: 3$ \\
\hline MSc or PhD holders & n.a. & n.a. & n.a. & n.a. & n.a. & n.a. & n.a. & n.a. & -4.678 & 6.589 & 0.478 & 0.009 \\
\hline University graduates & - & - & - & - & - & - & - & - & - & - & - & - \\
\hline TEl graduates & 0.379 & 0.327 & 0.247 & 1.461 & -0.874 & 0.55 & 0.112 & 0.417 & 0.459 & 0.563 & 0.414 & 1.583 \\
\hline 12 years of schooling & 0.405 & 0.242 & 0.094 & 1.499 & 0.342 & 0.422 & 0.418 & 1.407 & 0.136 & 0.511 & 0.79 & 1.1415 \\
\hline 9 years compulsory education & 0.206 & 0.281 & 0.465 & 1.228 & 0.927 & 0.479 & 0.053 & 2.527 & 1.477 & 0.587 & 0.012 & 4.379 \\
\hline Primary school graduates and & 0.207 & 0.26 & 0.427 & 1.23 & 0.612 & 0.452 & 0.176 & 1.843 & 2.191 & 0.589 & 0 & 8.9415 \\
\hline Urban areas & 0.511 & 0.153 & 0.001 & 1.667 & 0.731 & 0.268 & 0.006 & 2.077 & 0.038 & 0.293 & 0.898 & $1.03 i 3$ \\
\hline Rurial areas & - & - & - & - & - & - & - & - & - & - & - & - \\
\hline Apprenticeship & 0.566 & 0.482 & 0.24 & 1.761 & -0.959 & 0.468 & 0.041 & 0.383 & n.a. & n.a. & n.a. & n.a. \\
\hline Intra-firm training & -3.014 & 7.538 & 0.689 & 0.049 & -0.121 & 1.496 & 0.936 & 0.886 & n.a. & n.a. & n.a. & n.a. \\
\hline CVT & 0.054 & 0.69 & 0.938 & 1.055 & -2.683 & 0.802 & 0.001 & 0.068 & n.a. & n.a. & n.a. & n.a. \\
\hline Popular training & n.a. & n.a. & n.a. & n.a. & 0.213 & 1.301 & 0.87 & 1.238 & n.a. & n.a. & n.a. & n.a. \\
\hline Nori-participation in training & - & - & - & - & - & - & - & - & $n$ & $n$ & n & $n$ \\
\hline course(s) & 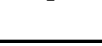 & 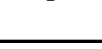 & - & - & - & - & - & - & n.d. & n.d. & n.d. & n.d. \\
\hline Time of training completion & n.a. & n.a. & n.a. & n.a. & 2.944 & 1.043 & 0.005 & 18.985 & n.a. & n.a. & n.a. & n.a. \\
\hline Registered in OAED & 2.791 & 0.249 & 0 & 16.299 & 3.553 & 0.272 & 0 & 34.918 & 3.917 & 0.306 & 0 & 50.25 .6 \\
\hline Nori-immigrants & 1.518 & 0.687 & 0.027 & 4.564 & -2.246 & 0.844 & 0.008 & 0.106 & 2.42 & 1.194 & 0.043 & 11.251 \\
\hline Constant & -1.5 & 0.281 & 0 & 0.223 & 0.142 & 0.98 & 0.885 & 1.152 & -5.499 & 1.396 & 0 & 0.004 \\
\hline
\end{tabular}

Also, the 1994 and 2000 findings do not confirm the human capital theory that the more 
education one receives the more chances he has on employment. Also, the variable "time of training completion" was found to be statistically significant; this means that trainees who had completed a course during the period 1998-2000 were more likely to be unemployed than those participating in previous years.

Only for 2006 the age group 25-34 was found to be statistically non-significant. Also, for 2006 marital status is statistically non-significant like in 2000, whereas high-school graduates and primary school graduates were less likely to be employed than University degree holders, unlikely 1994 and 2000 (statistically non-significant). For 2006, whether or not someone is an MSc or PhD holder does not make any difference, namely it was found statistically non-significant (data for postgraduates are not available in 1994 and 2000 in the LFS sample for Eastern Macedonia and Thrace). In the domain of residence location, only "semi-urban areas" was found to be statistically significant (less likely to be unemployed than people in rural areas) for 2006, unlikely 1994 and 2000.

\subsection{Interaction effect among variables}

For the 1994 and 2000 samples, did we fit the interaction effects between training and urbanisation level, and between training and level of education, as well as between age group and participation in training courses. Interactions terms were not found to be statistically significant in all three regions. Therefore, the variable "training" does not alter the relationship between unemployment and education, unemployment and age group, as well as unemployment and urbanisation level. In other words, the chances of finding a job do not change when we count training as an additional qualification in relation to residence location, age group and level of education.

\section{Conclusions}

This paper aims to present the odds of being employed in the three NUTS-2 Northern Greek regions during the implementation of the second (1994-99) and the third (2000-06) CSFs. More specifically, the analysis of social and demographic characteristics is disaggregated into the impact of gender, age, marital status, residence location, level of education, immigrant status, registered in the OAED and participation in training courses on the odds of being employed. Moreover, a second aim is to indicate whether University graduates face greater difficulties in finding a job than non-University graduates. The findings of the logit model employed are mixed, except from those registered in OAED for which the results have no differences among regions and years.

The results for gender are similar in the examined regions, namely, women were more likely to be unemployed than men. In 1994, people in the age group 15-24 years old were more likely to be unemployed than people in the age between 25 to 64 in all 
three regions. The age group 25-34 was found to be statistically non-significant in Western Macedonia in 2000 and Eastern Macedonia \& Thrace in 2006. The findings for marital status and level of urbanization are mixed, apart from the semi-urban areas in 2000 (statistically non-significant in all three regions).

The 1994 and 2000 findings in the RCM confirm the human capital theory that the more education one receives the more chances he has on employment; the results for 2006 differ from 1994 and 2000 in MSc or PhD holders (more likely to be unemployed than university graduates). In the domain of education for the RCM there are differences in the outcomes among the three years under examination. Also, in all three years in the RCM, TEI graduates were found to be statistically non-significant. The 1994 and 2000 (in part) findings in Western Macedonia confirm the human capital theory that the more education one receives the more chances he has on employment; for 2006 all educational categories were found to be statistically non-significant. In addition, in Eastern Macedonia and Thrace, for 1994 all educational categories were not found significant; also, the 1994 and 2000 findings do not confirm the human capital theory that the more education one receives the more chances he has on employment. Also, for Eastern Macedonia and Thrace, high-school graduates and primary school graduates were less likely to be employed than University degree holders, unlikely 1994 and 2000 (statistically non-significant). For 2006, whether or not someone is an MSc or PhD holder does not make any difference, namely it was found statistically non-significant (data for postgraduates are not available in 1994 and 2000 in the LFS sample for Eastern Macedonia and Thrace).

None of the four types of training programmes seemed to reduce the odds of unemployment for 1994 and 2000 (participation in CVT appears even worse prospects in the labour market than non-participation in Western Macedonia). Namely, all training variables were found to be statistically non-significant; this means that the results of training variables are not compatible with the human capital theory, so the more trained a person did not affect his chances of finding a job, in the RCM and Western Macedonia, during this period. All training variables are statistically non-significant for 1994 and 2000 in both regions (as already mentioned in section 4, we cannot explore training in 2006 due to the limitations of data); so, the results of the logistic regression confirm the conclusions of the various studies for the limited impact of vocational training in Greece. However, since there is always the question of wages which we cannot examine, there is nothing incompatible with rational economic decision making in searching longer for a job, if the expected wage gain is sufficiently high.

For 2000 the results for two types of training - "apprenticeship" and "CVT" (less likely to be unemployed than the non-trainees) - in Eastern Macedonia and Thrace are 
unique not only in comparison to the rest of Northern Greek regions examined in this paper, but also in relation to other Greek NUTS-2 areas and the entire country evaluated from 1992 to 2006. For Eastern Macedonia and Thrace only the 1994 results on training are like in the RCM and Western Macedonia.

Testing of interactions between training programmes and education, training courses and age, and training programmes and residence location, did not verify any significant pair. Thus, it is also to the productive structure of the examined areas that this effect is linked; the demand for qualified workers and real income might be raised by economic policies aimed at encouraging high quality services.

Also, the variable on time of training completion (namely, how many years before the survey has the interviewee finished the training programme(s) was found to be statistically non-significant, in the RCM and Western Macedonia. To the contrary, the variable "time of training completion" in Eastern Macedonia and Thrace was found to be statistically significant which means that trainees who had completed a course during the period 1998-2000 were more likely to be unemployed than those participating in previous years.

The variable "immigrant status" was found to be statistically significant in the RCM only for 1994, namely that year the immigrants were more likely to be employed than the Greeks. For 1994 in the RCM the native labour force was found to be in a less advantageous position in the labour market than the immigrant manpower, whereas in 2000 and 2006 this does not make any difference. In Western Macedonia the variable "immigrant status" was found to be statistically significant for 1994 (namely that year the immigrants were more likely to be employed than the Greeks) and 2006 (more likely to be unemployed than the native labour force). Also, the variable "immigrant status" was found to be statistically significant in Eastern Macedonia and Thrace for all three years; however, for 1994 and 2006 the immigrants were more likely to be employed than the Greeks, whereas the opposite was in force for 2000.

Also, in all years and in all three regions, people who were registered in OAED were less likely to be employed.

\section{References}

Albrecht J., van den Berg G.J. and Vroman S. (2005), The knowledge lift: The Swedish Adult Education Program that aimed to eliminate low worker skill levels, IZA Discussion Paper 1503, Bonn.

Arellano F.A. (2005), Do training programmes get the unemployed back to work? A look at the Spanish experience, Working Paper 05-25, Economics Series 15, Departamento de Economia, Universidad Carlos III de Madrid. 
Balourdos D. and Chryssakis M. (1998), Programmes of continuing vocational training: Statistical indications, evaluation and perspectives (in Greek), in Maratou-Alipranti L. and Hatzigianni A. (eds), Unemployment, employment, education-training in Greece and France. Proceedings of the Franco-Hellenic Colloquium, EKKE, Athens, pp. 133-150.

Biewen M., Fitzenberger B., Osikominu A. and Waller M. (2007), Which program for whom? Evidence on the comparative effectiveness of public sponsored training programs in Germany, IZA Discussion Paper 2885, IZA, Bonn.

Bjorklund A. and Regner H. (1996), Experimental evaluation of European labour market policy, in Schmid G., O'Reilly J. and Schomann K. (eds), International handbook of labour market policy and evaluation, Edward Elgar, Aldershot, UK, pp. 89-114.

Brodaty T., Crepon B. and Fougere D. (2001), Using matching estimators to evaluate alternative youth employment programs: Evidence from France, 1986-1988, in Lechner M. and Pfeiffer F. (eds), Econometric evaluation of labour market policies, Physica, Heidelberg.

Calmfors L. and Skedinger P. (1995), Does active labour-market policy increase employment? Theoretical considerations and some empirical evidence from Sweden, Oxford Review of Economic Policy, vol. 11, No 1, pp. 91-109.

Cavaco S., Fougere D. and Pouget J. (2005), Estimating the effect of a retraining program for displaced workers on their transition to permanent jobs, IZA Discussion Paper 1513, Bonn.

Chletsos M. (1998), The education as an active employment policy: Limits and preconditions of implementation. The case of Greece (in Greek), in Maratou-Alipranti L. and Hatzigianni A. (eds), Unemployment, employment, education-training in Greece and France. Proceedings of the Franco-Hellenic Colloquium, EKKE, Athens, pp. 151-179.

Christodoulakis N. and Kalyvitis S. (1995), Likely effects of the CSF 1994-1999 on the Greek economy, Discussion Paper No 46, KEPE, Athens.

Chryssakis M. (1991), Uneven access to tertiary education: The impact of educational changes, in Petralias N. (ed), The University in Greece, Today, Foundation of Sakis Karagiorgas, Athens, (in Greek).

Chryssakis M. and Soulis S. (2001), Inequalities in access to University education: An approach to official data, Panepistimio, 3 (in Greek).

Cockx B. (2003), Vocational training of unemployed workers in Belgium, Applied Economics Quarterly, 49 (1), pp. 23-48.

Cockx B., van der Linden B. and Karaa A. (1998), Active labour market policies and job tenure, Oxford Economic Papers, vol. 50, No 4, pp. 685-708. 
Cueto B. and Mato F. J. (2009), A non-experimental evaluation of training programmes: Regional evidence for Spain, The Annals of Regional Science, vol. 43, No 2, pp. 415-433.

Economic and Social Committee of Greece (1998), Opinion of Initiative for the "Vocational Training", Athens, June (in Greek).

ESYE (National Statistical Service of Greece, 1991-2006), Statistical Yearbook and Labour Force Survey.

EUROSTAT (1995), Education and employment prospects.

Fay R. (1996), Enhancing the effectiveness of active labour market policies: Evidence from programme evaluations in OECD countries, Labour Market and Social Policy occasional papers, No 18, OECD, Paris.

Gravaris D. (1991), The politico-economic foundations of employment policies (in Greek), Topos: Review of Urban and Regional Studies, No 3, pp. 3-36.

Hämäläinen K. and Ollikainen V. (2004), Differential effects of Active Labor Market Programmes in the early stages of young people's unemployment, VATT Research Reports 115, Helsinki.

Heckman J. J., LaLonde R. J. and Smith J. A. (1999), The economics and econometrics of active labour market programs, in Ashenfelter O. and Card D. (eds), Handbook of Labor Economics, volume 3A, Elsevier, Amsterdam, pp. 1865-2097.

Iliades N. (1995), Continuing vocational training in Greece, National Report (in the context of FORCE), National Institute of Labour, January (in Greek).

IN.E./GSEE (Institute of Labour/General Confederation of Workers of Greece) - ADEDY (Civil Servants' Supreme Administrative Council) (1999), The Greek economy and the employment, Annual Report, Reports No 1, Athens, August (in Greek).

Jackman R. (1995), What can active labour market policy do?, Discussion Paper No 226, CEP, LSE.

Katsikas C. (2005), Studies-Vocation and labour market, Atrapos Publishing, Athens (in Greek).

Katsikas C. and Kavvadias G. (1994), Inequalities in Greek education, Gutenberg, Athens (in Greek).

Katsikas E. and Panagiotidis T. (2011), Student status and academic performance: Accounting for the symptom of long duration of studies in Greece, Studies in Educational Evaluation, 37, pp. 152-161. 
Kluve J. (2010), The effectiveness of European Active Labor Market Programs, Labour Economics, 17 (6), pp. 904-918.

Kluve J. and Schmidt C. M. (2002), Can training and employment subsidies combat European unemployment?, Economic Policy, vol. 17, No 35, pp. 411-448.

Kluve J., Lehmann H. and Schmidt C. M. (1999), Active labour market policies in Poland: Human capital enhancement, stigmatization, or benefit churning?, Journal of Comparative Economics, vol. 27 (1), pp. 61-89.

Kyridis A. (1997), Inequalities in Greek education and access to the University, Gutenberg, Athens (in Greek).

Lechner M., Miquel R. and Wunsch C. (2007), The curse and blessing of training the unemployed in a changing economy: The case of East Germany after unification, German Economic Review, vol. 8, No 4, pp. 468-509.

Linardos-Rylmon P. (1998), Vocational training and labour market: Indispensable changes into the function of the continuing training system in Greece (in Greek), in MaratouAlipranti L. and Hatzigianni A. (eds), Unemployment, employment, education-training in Greece and France. Proceedings of the Franco-Hellenic Colloquium, EKKE, Athens, pp. 233-236.

Malmberg-Heimonen I. and Vuori J. (2005), Activation or discouragement - The effect of enforced participation on the success of job-search training, European Journal of Social Work, 8 (4), pp. 451-467.

Meadows P. and Metcalf H. (2008), Does literacy and numeracy training for adults increase employment and employability? Evidence from the Skills for Life programme in England, Industrial Relations Journal, 39 (5), pp .354-369.

Meghir C., Ioannides Y. and Pissarides C. (1989), Female participation and male unemployment duration in Greece, European Economic Review, vol. 33, Nos 2-3, pp. 395 406.

Ministry of Education (2008), Educational statistical data, at http://www.alfavita.gr/OdigosEkpaideytikou/odigos20061227a.php, last retrieved February 16, 2009.

(OUT) Murray A. and Steedman H. (1998), Growing skills in Europe: The changing skills profiles of France, Germany, the Netherlands, Portugal, Sweden and the UK, TSER, Discussion Paper No 399, CEP, LSE.

OECD (1990), Employment Outlook, OECD, Paris. 
OECD (1993), Active labour market policies: Assessing macro-economic and microeconomic effects, Employment Outlook, ch. 2, OECD, Paris, pp. 39-80.

OECD (1999), Employment Outlook, OECD, Paris.

Papakonstantinou G. (1998), Education-training as factors of investment in human capital (in Greek), in Maratou-Alipranti L. and Hatzigianni A. (eds), Unemployment, employment, education-training in Greece and France. Proceedings of the Franco-Hellenic Colloquium, EKKE, Athens, pp. 125-132.

Papas G. and Psacharopoulos G. (1991), The determinants of educational achievement in Greece, Studies in Educational Evaluation, 17 (1), pp. 405-418.

Patrinos H.A. (1992), Higher education finance and economic inequality in Greece, Comparative Education Review, 36(3), pp. 298-308.

Psacharopoulos G. and Tassoulas S. (2004), Achievement at the higher education entry examinations in Greece: A Procrustean approach, Higher Education, 47 (2), pp. 241-252.

Regner H. (2002), A non-experimental evaluation of training programmes for the unemployed in Sweden, Labour Economics, vol. 9 (2), pp. 187-206.

Rodokanakis S. (2009), Comparing the probability of unemployment in Southern Greece visà-vis the entire country, Bulletin of Geography - Socio-economic Series, No 12, pp. 17-43.

Rodokanakis S. (2010), The dynamics of regional labour markets and training programmes: Greek evidence, European Spatial Research and Policy, vol. 17, No 1, pp. 93-115.

Rodokanakis S. (2011), Measuring the unemployment risk in Greece as a whole from the LFS micro-data: Comparison among the three CSFs, Proceedings (CD-Rom) following a selection of papers presented at the $17^{\text {th }}$ European Colloquium on Quantitative and Theoretical Geography (ECQTG2011), Athens, 2-5 Sep., pp. 492-499.

Rodokanakis S. and Tryfonidis D. (2008), The probability of being unemployed in the three Northern Greek regions during the CSF-1: Econometric analysis of the LFS micro-data [following a selection of papers presented at the International Conference on Applied Economics (ICOAE) 2008, Kastoria, Greece, 15-17 May], Journal of European Economy, vol. 7, special issue, pp. 332-347.

Rodokanakis S. and Tryfonidis D. (2009), Unemployment hazard in the Aegean islands: Econometric analysis of the LFS micro-data, in Brox J. A. and Baltas N. (eds), The global economics of a changing environment: Studies in the structure, performance and reform of economics, organizations and business throughout the globe, chapter 14, North Waterloo Academic Press, Waterloo, Canada, June, pp. 211-224. 
Rodokanakis S. and Vlachos V. (2012), Assessing the probability of employment in Greece between the 2004 Olympics and the global financial crisis: The cases of the Northern Aegean and Ionian islands, International Journal of Employment Studies, vol. 20, No 2, pp. 91-108.

Rosholm M. and Skipper L. (2009), Is labour market training a curse for the unemployed? Evidence from a social experiment, Journal of Applied Econometrics, 24(2), pp. 338-365.

Rosholm M. and Svarer M. (2004), Estimating the threat effect of Active Labor Market Programs, Working Paper No 6, Department of Economics, University of Aarhus.

Stanley M., Katz L. and Krueger A. B. (1999), Impacts of employment and training programs: The American experience, unpublished manuscript, Harvard University.

Stenberg A. (2005), Comprehensive education for the unemployed - Evaluating the effects on unemployment of the Adult Education Initiative in Sweden, Labour, vol. 19, No 1, pp. 123146.

Torp H. (1994), The impact of training on employment: Assessing a Norwegian labour market programme, Scandinavian Journal of Economics, vol. 96, No 4, pp. 531-550.

Tsakloglou P. and Choletzas I. (2005), Education and inequality in Greece, IZA Discussion Paper No 1582, IZA, Bonn.

Winter-Ebmer R. (2006), Coping with a structural crisis: Evaluating an innovative redundancy-retraining project, International Journal of Manpower, 27 (8), pp. 700-721.

www.economics.gr

Zweimuller J. and Winter-Ebmer R. (1996), Manpower training programmes and employment stability, Economica, 63 (249), pp. 113-130. 